\title{
FINANCIAL GLOBALIZATION, INSTITUTIONS AND ECONOMIC GROWTH IMPACT ON FINANCIAL SECTOR DEVELOPMENT IN FRAGILE COUNTRIES USING GMM ESTIMATOR
}

DOI: 10.17261/Pressacademia.2021.1382

JBEF- V.10-ISS.1-2021(4)-p.36-46

Tuba Gulcemal

Sivas Cumhuriyet University, Faculty of Tourism, Sivas, Turkey. tgulcemal@cumhuriyet.edu.tr, ORCID 0000-0003-4806-8568

\begin{tabular}{l} 
Date Received: December 5, $2020 \quad$ Date Accepted: March 22, 2021 \\
\hline To cite this document \\
Gulcemal, Tuba (2021). Financial globalization, institutions and economic growth impact on financial sector development in fragile \\
countries using GMM estimator. Journal of Business, Economics and Finance (JBEF), V.10(1), p.36-46. \\
Permanent link to this document: $h$ ttp://doi.org/10.17261/Pressacademia.2021.1382 \\
Copyright: Published by PressAcademia and limited licensed re-use rights only.
\end{tabular}

\section{ABSTRACT}

Purpose- The aim of the research is to predict the impact of financial globalization, institutional quality and economic growth on financial development in fragile economies. In this paper the panel data consists of Turkey, Brazil, India, South Africa, Indonesia, Argentina, Egypt, Pakistan's annual data from 1995-2017.

Methodology -System GMM dynamic panel data approach has been applied to deal with simultaneity bias and endogeneity bias when the explanatory variable is correlated with the residual disturbance term. The System GMM estimator combines regression in differences with regression in levels to get rid of the individual specific effects and along with it any time invariant regressor. The models are estimated by using one step system GMM estimator in other words Arellano and Bover /Blundell and Bond System Generalized Moments Method. Findings- The results show that economic growth and financial development are positively related. Thanks to financial development interest rates can be determined by market conditions and financial intermediaries can minimize transaction costs and information acquisition costs can be minimized. Empirical findings suggest policy guidelines for developing financial sector by using economic growth as an economic instrument.

Conclusion- The paper concludes that economic growth have significant impact on financial development so both financial institutions and financial markets development in fragile countries. For less developed countries, developments in institutions are likely to have far greater direct effects on growth than financial development itself. When the financial system is developed, Institutional improvements can also deliver more growth. Since global standards for institutions such as International Country Risk Guide, Global Government Indicators increase, it seems also developing ountries are aware of the importance of institutional quality on economic growth. The findings suggest that financial development is affected by economic growth, inflation and population in fragile countries.

Keywords: Financial development, economic growth, GMM dynamic panel data analysis, fragile countries JEL Codes: F65, G10, G20

\section{INTRODUCTION}

With the progress of globalization, the effects of financial sector development and institutional quality on economic growth in developing and developed countries have increased and has been highly researched in the recent years. Opening financial markets to foreign capital directly, increases access to capital and lowers investment costs. Many emerging economies with a high degree of financial integration have higher growth rates. Additionally, differences in the degree of globalization, financial sector depth and intitutional quality between developing and developing countries are significant (Dreher, 2006).

A financial system involved in financial globalization is expected to have a high level of financial development because financial globalization will defeat informal and advantageous information in financial markets. Because the financial system will disseminate all available information, as a result of conflicts and new demands of the external economic actors. It is practicable that with financial globalization the best practices and methods of financial supervision spread around the world and improve corporate governance.

Financial globalization also favors risk diversification because local economic institutions can share risks with foreign institutions in local and foreign exchange markets. Thus, a country can lend to a foreigner and borrow in a recession, which helps mitigate the up-and-down effects on income levels, consumption and investment. Free movement of capital around 
the world will support global mobilization and accumulation of savings. Domestic savings will be able to seek foreign financial markets seeking better returns and the domestic financial market will have to develop methods to accumulate savings because of international competition. And financial globalization reduces international transaction costs and supports a global relationship between finance and the real sector. In other words, globalization facilitates exchanges in the real economy on a global scale (Demetrio and Garcia; 2012:158-159). Besides all this, the financial uncertainty is a feature of globalization. Increasing foreign capital inflows doesn't always mean faster economic growth (Prasad, Rajan and Subramanian, 2007). Uncertainty is high in developing countries as known and could potentially return more when they share risk. However, financial integration also causes a change in the value of steady state capital stocks, affecting the distribution of risk among countries. Risky countries will also see capital outflows and production decline as their prudential savings are reallocated to developed countries, unless they experience a shortage of capital. When riskier countries also experience significant capital shortages, the standard efficiency gains from faster convergence are greatly reduced by reallocating prudential savings.

Many empirical studies have provided convincing evidence to support the view that institutional quality differences can also have a significant impact on economic performance. A properly functioning financial market helps meet borrowers and lenders by channeling resources to the funding options. A high level of investment increases employment opportunities, improves public finances and helps to reduce poverty due to the growing economic activities. Institutions consist of 'set of rules, compliance procedures, moral and ethical norms' designed to limit behaviour in order to maximize the benefits of principals.

Liberalization, globalization and technological advances in a country have helped equity market integration through the creation of stock exchange networks. In some countries, the effectiveness of financial institutions leads to economic growth, while in others, economic growth increases the depth and impact of financial institutions, differences in the quality of financial institutions can have a big impact on economic performance.

Financial sector plays an important role in the efficient allocation of scant economic resources, and its rapid tempo leads to an increase in total factor productivity. Financial market effectiveness and competitiveness assist economic growth.

The purpose of this article is to explore the impact of financial globalization, institutional quality and economic growth on financial development using the panel data for fragile countries. "Fragile Five" is a term created in 2013 by Morgan Stanley to represent some emerging market economies that had become too rely on volatile foreign investment to fund their growth prospects. The original five members of the fragile five cover Turkey, Brazil, India, South Africa and Indonesia (https://www.morganstanley.com). After the 2008 financial crisis, investors began to transfer money from the emerging markets to the U.S. dollar and developed countries. These escapes mainly from Brazil, India, Indonesia, South Africa, and Turkey. Their currencies, the Brazilian real, the Indian rupee, the Indonesian rupiah, the South African rand, and the Turkish lira experienced significant weakness and made it harder to fund account deficits. These countries are similar to each other in terms of high inflation rates, high current account deficits, uncertainties in capital flows, some economic features, such as instability in growth performances. After 2013, in November 2017, credit rating agency S\&P Global has also described the countries of Turkey, Argentina, Pakistan, Egypt and Qatar as the "Fragile Five" because they have been so negatively affected by rising interest rates. According to some analysts, India and Indonesia are now a safe haven for investors at the time of the trade war. Turkey is the only country in which both the old and the new fragile five status. In this paper our dataset consists of Turkey, Brazil, India, South Africa, Indonesia, Argentina, Egypt, Pakistan's annual data.

In this study, the system GMM dynamic panel data approach was applied to cope with the simultaneity and endogeneity bias caused by the possible correlation of financial development with economic growth and financial institutions.

\section{LITERATUR REVIEW}

The issue of the impact of the financial market on economic growth was first raised almost 150 years ago within the classical school. In the early 20th century, J. Schumpeter (1912) examined the issue applying it to the theory of entrepreneurship. Later, due to objective factors - two world wars and the Great Depression - the issue of relation between the financial market and economic growth was out of the scope of the economic science. Since the early 1960s, there has been a steady increase in interest in this issue: first large-scale research of mainly historical and economic nature, were carried out. In the 1970s-1980s, there were works which rejected a verbal description of the influence of the financial market on economic growth in a particular country or countries in favor of building theoretical models, including those based on economic and mathematical methods, taking into account the determinnig factor of financial development: openness, political power, political institutions, financial liberalization, legal traditions, economic institutions, macroeconomic determinants, as well as determinants that characterize culture and geography (Voghouei et al., 2011, La Porta, et al., 2002, Acemoglu, et al., 2001, Acemoglu, et al., 2005, Acemoglu and Robinson, 2006) The increasing significance of the financial markets for the global economy, processes of its liberalization, development of the finance theory and emergence of new models of economic growth encouraged the active growth of scientific knowledge in this area. 
Lipset (1959) pointed out that economic growth resulted in higher quality institutions due to capital accumulation and public capital. In this sense, as people's welfare level increases, demands for higher institutional quality, better bureaucratic conditions, more legal and legal regulation will increase (Nasreen, Mahalik, Shahbaz and Abbas, 2020:2). And also Barro (1996) noted that by supporting the positive impact of economic growth on institutional quality in a country, citizens in that country gain more political freedom.

Despite the numerous studies in the literature that support the impact of financial development on economic growth in the past years (Schumpeter, 1912; Gurley and Shaw, 1967). Rajan and Zingales (1998) concluded that the economic growth has a positive effect on financial system and development in their study. Their study suggest that economic growth leads to further development of the financial system and also provides incentives for deepening and expanding the system for financial mediation (Nasreen, Mahalik, Shahbaz and Abbas, 2020:2).

Mishkin (2009) and Demetrio and Garcia (2012) argued that globalization leads to increasing the growth of the financial sector and hence contribute positively to economic growth of a country and also the bureaucracy, property rights, governance and political stability contributed to positive economic growth. According to them, globalization is a crucial factor in promoting institutional reform that promotes financial development and economic growth in developing countries. By encouraging developing countries to increase their participation in global markets, developed countries can create exactly the right incentives for developing countries to implement reforms that will drive their high economic growth. Chong and Calderon (2000) argued that there is causality between financial institutions and economic growth, and vice versa. Mishkin (2009) reported that the institutions quality serve growth of the economy by improving financial sector.

Levin, Loayze and Beck (2000) examined the growth and finance relationship using panel data from 71 countries for the period 1960-1995 and found a positive relationship between them. Odhiambo (2011), in South Africa analysed the dynamic relationship between financial development and economic growth and determined a causal relationship between financial depth and economic growth. Moreover, Rajan and Zingales (2003) compared the characteristics of European financial system. They have concluded that financial system of European countries has moved from a bank-based system to a market-based system. The ongoing process may result in a further development of the market-based system over time.

Demetrio and Garcia (2012) researched the impact of financial globalization on financial development in transition countries using the dynamic panel data analysis. The main results suggest mostly that financial globalization has a positive and significant relationship with the process of growth of the financial system. The basic hypothesis is that financial development is positively dependent on the level of financial globalization, and furthermore, financial development is positively dependent on some control variables other than the rate of inflation (Demetrio and Garcia, 2012:162). Luo, Zhang and Zhu (2016) in China, using time series analysis, found that commercial and financial openness had valuable effects on financial performance but also negative effects on the size of financial development. Muye and Muye (2017), also found positive long-run relationship between globalization and financial development for the BRICS countries, using the time series data.

Additionally, Khan, Khan and Abdulahi et. al (2019) used the International Monetary Fund's (IMF) dataset for financial development which is considered the most comprehensive measure. According to the results, based on a strong cointegration method, definitively verify that institutional quality is required for financial development in the United States. It turned out that there was a negative relationship between natural resource rent and financial development when appropriate control variables to the model were also added. This study examines that institutional quality modulates the link between natural resource rent and finance. As a result, they have advised policymakers and researchers to produce realistic forecasts and policy inputs, taking into account the importance of institutions.

Nasreen, Mahalik, Shahbaz and Abbas (2020) examined the role of financial globalization, institutions and economic growth on the development of the financial sector using panel data of European countries for the period 1989-2016. The empirical results indicate like as Rodrik's (1997) and Law, Kutan and Naseem's (2018); economic growth and institutional quality are positively associated with financial development, but apart from this, financial globalization blocks the development performance of the financial sector.

Le (2020) identified the link between energy consumption and economic growth with a comprehensive assessment of the impact of institution quality, government spending, financial development and commercial freedom bu using panel econometric estimate model with data from 1990 to 2014 for 46 emerging markets and emerging economies. The findings show that energy consumption, gross fixed capital formation, government spending, financial development and trade openness positively and significantly affect economic growth. According the test results, energy consumption and economic growth are interconnected and that provides a basis for policy makers to design effective energy and environmental policies. Taking into account the sustainable development goal, governments were advised to consider the importance of financial governance-trade relations for economic growth, as well as the performance of energy-effective programme.

Another study about financial development and economic growth examined by Yıldız and Atasaygın (2015) in Turkey. By analyzing the relationship between financial deepening and economic growth using the ECM co-integration approach, they 
showed that there is a long-term relationship between financial development and economic growth and that the demand pull hypothes is acceptable for the Turkish economy.

Chen and Quang (2014) analysed the circumstances under which international financial integration increases growth. Based on non-linear dynamic panel techniques, they found that countries that can benefit from international financial integration meet certain threshold conditions for economic, institutional and financial development and the level of government spending. The results also differentiated portfolio equity liabilities compared to other types of capital flows and Financial Development Index are systematically less restrictive for the former and growth behavior the effects of the threshold conditions is significantly greater.

Şamiloğlu and Savaş's study (2010) conducted in Turkey, the effect of financial development on economic growth was investigated using the ARDL boundary test. This study also concluded that financial development is a long-term process promoted by economic wealth. Then again, according to the results domestic loans provided by the banking sector affect economic growth and Granger causality test results were obtained that support the supply-leading hypothesis in the long term and the hypotheses that both drive supply and demand following in the short term.

The underdeveloped countries that have experienced financial crisis; Mexico (1994-1995), Asia (1997), Russia (1998), Brazil (1998-1999), Argentina (2000-2001) and the United States (2007-2008) and also Europe (2011). It is clear that financial crises and their easy transmission are the basic warning signals against financial globalization (Demetrio and Garcia; 2012:157). Financial development helps distribute capital; accelerates growth and stages of economic development. In the early stages of economic development, people with savings in hand only entered financial markets to enjoy access to financial markets and to enjoy the benefits of financial services. At higher levels of economic development, the number of people accessing the financial market subsequently increased causing financial development (Kavya and Shijin;2020:81).

General moves in capital flows and asset prices in emerging market economies are mainly driven by two global factors; global risk averting and US monetary policy (Rey, 2013). In 2019, as a result of tighter financial conditions, lower domestic demand or currency depreciation, current account balances rose toward surplus in some emerging market and developing economies like as Argentina, South Africa and Turkey. The currencies of Brazil, South Africa and Turkey depreciated vis-à vis the US dollar by 8 percent to 14 percent, also with smaller real effective depreciations (https://www.imf.org).

In the literature, the results of the empiric tests usually indicate a positive effect of globalization on financial development, notably in developed countries. But the results for underdeveloped countries are complex but the positive effect has been seen in emerging economies. Furthermore, the test results after adding the financial institutional factors show that the impact of financial globalization on financial development will be positive only if financial institutions in a country are of quality.

\section{DATA AND METHODOLOGY}

The three models are estimated by using one step system GMM estimator. The dependent variables according to the three models established are financial development, financial institutions and financial markets. In this section, information about the variables used in the analysis and the method is given. The dependent and independent variables and description in three models set up to analyze are as follows:

\section{Financial Globalization Index (KOFFGI)}

The Konjunkturforschungsstelle (KOF) Globalization Index was used to evaluate these relationships; the KOF calculation method addresses globalization's economic, social and political aspects (https://ethz.ch). It is used to monitor changes in the levels of globalisation of different countries over a long period. KOF Globalization Index is calculated for 195 countries and based on the period from 1970 to 2017. In this study, new measures developed by the KOF financial Globalization Index were implemented, together with several economic factors, to more rigorously analyze how the financial globalization indicator affects economic growth.

Gygli, Haelg, Potrafke and Sturm (2019) reconsidered the KOF globalization index dividing it into de-facto and de-jure. The KOF de-facto measures consist of that variables (all variables are expressed as a percentage of GDP): the sum of foreign assets and liabilities, sum of international equity portfolio investment assets and liabilities, sum of international portfolio debt securities and international bank loans and deposits, international reserve excluding gold and sum of primary income and receipts (Nasreen, Mahalik, Shahbaz and Abbas, 2020:5). The KOF de-jure measures of financial globalization comprises investment restrictions that include measures of the prevalence of foreign ownership and regulations to international capital flows, capital account openness index and capital account openness index. In this paper, The KOF financial Globalization Index developed by Gygli et. al (2019) is considered as a whole and its values for the countries that make up our sample are taken between 1995-2017. The new measures developed by the KOF Financial Globalisation Index, along with various economic elements to more meticulously analyze how financial globalization indicator affects on eonomic growth. In the analysis this variable symbolized by KOFFGI. 
Table 1: 2019 Financial Globalisation variables and weights in KOF Globalisation Index

\begin{tabular}{|l|l|l|l|}
\hline Variables & Weights & Variables & Weights \\
\hline Financial Globalisation, de facto & 50.0 & Financial Globalisation, de jure & 50 \\
\hline Foreign direct investment & 27.3 & Investment restrictions & 33.3 \\
\hline Portfolio investment & 16.9 & Capital account openness & 38.5 \\
\hline International debt & 27.6 & International Investment Agreements & 28.2 \\
\hline International reserves & 2.1 & & \\
\hline International income payments & 27.1 & & \\
\hline
\end{tabular}

Source: Gygli, S., Haelg, F., Potrafke, N. et al. (2019) The KOF Globalisation Index - revisited. Rev Int Organ. 14, $543-574$. https://doi.org/10.1007/s11558-019-09344-2, p.545.

\section{Financial Development Index (FDV}

In studies so far, various proxies have been used to compute the status of financial development. Multiple indicators to measure financial development should used across countries because of the diversity of financial systems. Instead of using a one-dimensional indicator to measure financial development, an index consisting of the sum of the financial institutions index and the financial markets index was used, in which different dimensions were also included in the index. Description of financial development index subcategories presented in Figure 1. below.

\section{Figure 1: Financial Development Index}

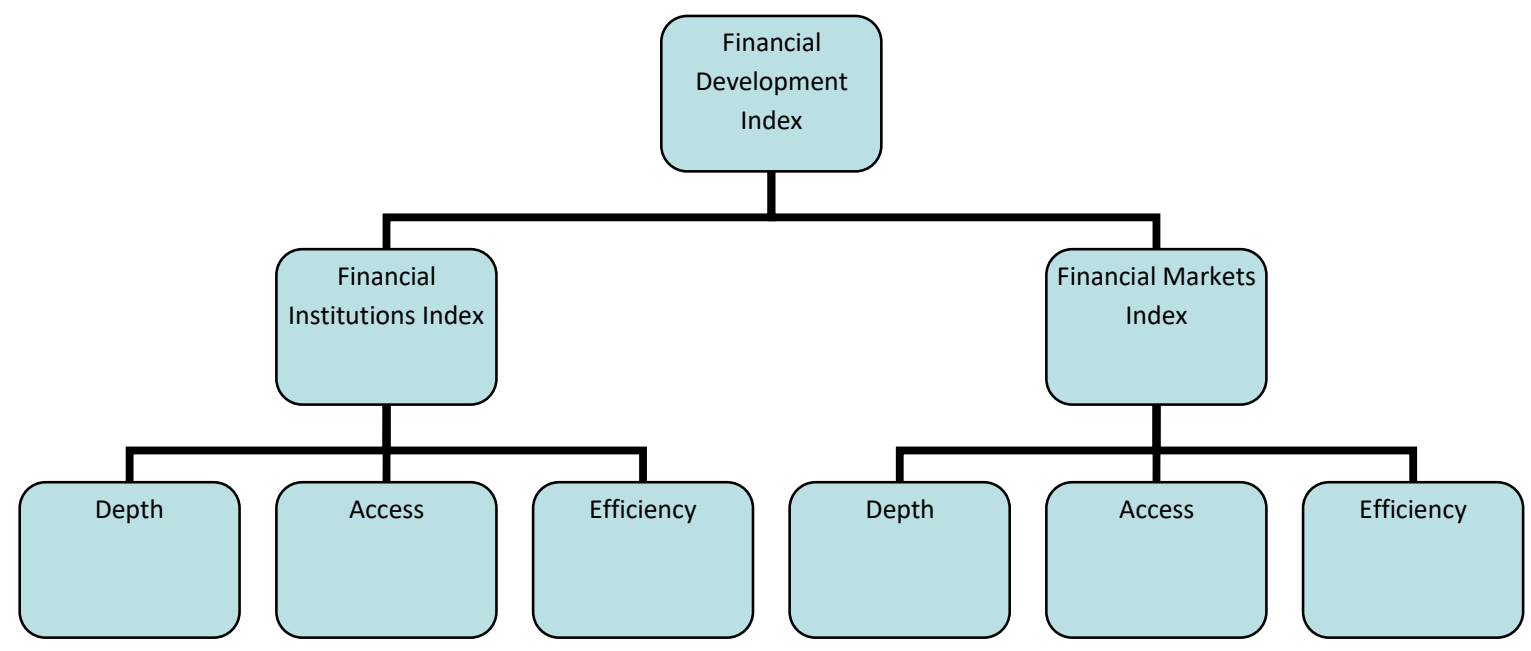

Source: https://data.imf.org/?sk=F8032E80-B36C-43B1-AC26-493C5B1CD33B

Financial sector consists of two main pillars; financial institutions and financial markets. The variables of Financial Institutions Index and Financial Markets Index subcomponents and also sources are presented in Table 2.

Table 2: Variable Names, Definitions and Sources

\begin{tabular}{|l|l|l|}
\hline Category & Indicators & Source \\
\hline Financial Institutions Index & & \\
\hline Depth & $\begin{array}{l}\text { Bank credit to the private sector, pension and mutual fund assets and } \\
\text { insurance premiums, life and non life }\end{array}$ & IMF \\
\hline Access & Bank branches and ATMs per 100.000 adults & IMF \\
\hline Efficiency & $\begin{array}{l}\text { Banking sector net interest margin, lending deposits spread, non- } \\
\text { interest income to total income, overhead costs to total assets, return } \\
\text { on assets and return on equity. }\end{array}$ & IMF \\
\hline Financial Markets Index & $\begin{array}{l}\text { Stock market capitalization, stocks traded, international debt } \\
\text { securities of government and total debt securities of financial and non } \\
\text { financial corporations }\end{array}$ & IMF \\
\hline Depth & Percent of market capitalization outside of top 10 largest companies & IMF \\
\hline Access & \multicolumn{1}{|l}{} \\
\hline
\end{tabular}




\begin{tabular}{|l|l|l|}
\hline & and total number of issuers of debt per 100.000 adults & \\
\hline Efficiency & Stock market turnover ratio & IMF \\
\hline
\end{tabular}

Source:https://data.imf.org

\section{Institutional quality (EFW)}

The world's Economic Freedom Index derived from the Fraser Institute used to measure the institutions that regulate the market. In a society that is economically independent, the most basic task of the state is to protect individuals and their property from aggression. The World Economic Freedom Index shows us whether a nation's institutions and policies are consistent with its protective function and individuals' rights to economic freedom (Economic Freedom of the World: 2019 Annual Report, The Fraser Institute). EFW Index consists of size of government, legal system and property rights, sound money, freedom to trade internationally and regulation.

\section{Economic growth (GDP)}

Gross domestic product (GDP) series is used as an indicator of economic growth in sample countries by making a logarithmic form with fixed \$ prices in 2010.

For analysis, control variables used with independent variables; sum of export and imports to GDP ratio which gives trade opennes, inflation (consumer price index) and population.

\section{Exports and imports to GDP ratio (Trade openness)}

It is the ratio of the sum of exports and imports to GDP. This variable explains the degree of economic integration between countries. Trade liberalization, which promotes a more competitive environment, will lower the revenue of entrenched firms so that they will need greater access to external sources of capital. Thus, they will be more likely to support reforms that promote a deeper and more efficient financial system (Mishkin, 2009:166).

\section{Inflation (INf)}

Inflation is a condition that refers to a constant and palpable increase in the overall level of goods and services prices. Another definition is that nominal national income increases compared to the amount of goods purchased with this income.

\section{Population (PP)}

A real development is the increase of trained and specialized workforce, it can happen if the entire population is under the umbrella of social security, and meanwhile the unemployment rate is 1 or 2 percent.

In this study, first dynamic model created to determine the relationship between $F D V_{i t}$, which represents financial development, $F D V_{i t-1}$ is the lagged value of financial development, $z_{i t}$ is the set of explanatory variables including financial globalization (KOFFGI), institutional quality index (EWF), economic growth (InGDP) and also inflation, population and trade to gdp ratio (trade openness).

$F D V_{t}=\beta F D V_{i t-1}+\mathcal{\gamma}^{t}[z]_{i t}+\psi_{i}+\mu_{i t}$

The term $\psi_{i}$ is a time-invariant country specific effect, $\mu_{i t}$ represents independently and identically distributed error term. The appearance of lagged value of financial development in empirical model indicates the presence of correlation between regressor and error term since lagged value of financial development depends on $\mu_{i t-1}$ which is a function of $\psi_{i}$ the country specific effect. Because of this correlation, dynamic model presented in 1. equation can have specification bias. The Arellano-Bond (1991) and Arellano-Bover (1995)/Blundell-Bond (1998) dynamic panel estimators method is able to correct time invariant country specific effect, omitted variable bias, measurement error and endogeneity problem. Arellano- Bond estimation starts by transforming all regressors by differrencing and uses the Generalized Method of Moments (Hansen 1982), and because of this called Difference GMM. The Arellano-Bover/Blundell-Bond estimator augments Arellano-Bond by making an additional assumption, that first differences of instrument variables are uncorrelated with the fixed effects. This allows the introduction of more instruments and can dramatically improve efficiency alleviating the weak instrument problem. It builds a system of two equations- the original equation as well as the transformed one-and is known as System GMM (Roodman,2006:1).

The efficiency of difference GMM estimation, however, is criticized in terms of bias and imprecision. A well-known property of difference GMM is that standard errors may be severely biased downwards in small samples. A more fundamental weakness of difference GMM is that lagged values of variables may be weak instruments for first difference, especially when the series are highly persistent. Thus situated, additional assumptions on the initial conditions of the process are required to improve the identification of the model. The System GMM estimator combines regression in differences with regression in levels to get rid of the individual specific effects and along with it any time invariant regressor. This also gets rid of any endogeneity that may be due to the correlation of these individual effects and the right hand side regressors. 
First difference control unobserved country heterogeneity, omitted variable bias and endogeneity problem. To achieve identification, level equation uses the lagged first differences of explanatory variables as instruments. The lagged dependent variable is specified as a "GMM-style" instrument, where all available lags will be used as separate instruments (Baum, 2014:23). The moment conditions utilize the orthogonality conditions between the differenced errors and lagged values of the dependent variable. The additional moments conditions are as shown below;

$E\left[\Delta F D V_{i t-r}\left(\psi_{i}+\mu_{i t}\right)\right]=0$ for $r=1$

$E\left[\Delta Z_{i t-r}\left(\psi_{i}+\mu_{i t}\right)\right]=0$ for $r=1$

This assumes that the original disturbances are serially uncorrelated. Specification tests suggested by Arellano and Bond (1991) and Blundell and Bond (1998) are used. The first test is a Sargen test of over identifying restriction which test the overall validity of instruments by analyzing the sample analog of moment conditions used in the estimation process neverthless too many moment conditions introduce bias while increasing efficiency. With respect to autocorrelation test, one should reject the null of the absence of first order serial correlation and not reject the absence of second order serial correlation. The second is difference in- Hansen test of too many instruments and the third is an autocorrelation test in disturbances (Baltagi, 2011:324).

There are two versions of system GMM estimators- the one step and two step estimators. Theoretically, two-step system GMM estimator uses optimal weighting matrix. The two-step estimator would just combine the $(T-1)$ first-differenced equations and the average level equation. In this paper, one-step System GMM estimator is applied. Xtabond 2 comand is applied to examine the effect of economic growth, financial globalization, institutional quality on financial development. In one-step GMM, xtabond2's robust is equivalent to cluster (id) in most other estimation commands, where id is the panel identifer variable, requesting standard errors that are robust to heteroskedasticity and arbitrary patterns of autocorrelation within individuals (Roodman, 2006:37).

\section{EMPIRICAL RESULTS}

Our goal in this paper is to examine the effect of economic growth, financial globalization, institutional quality along with other variables on combined index of financial development. The three models are estimated by using one step system GMM estimator, in other words Arellano and Bover /Blundell and Bond System Generalized Moments Method.

Table 3: System GMM Regression Analysis Using Financial Development as Dependent Variable

\begin{tabular}{|l|l|l|}
\hline \multicolumn{2}{|l|}{ Dependent variable: FDVit } & \\
\hline Variables & Coefficient & Standart Error \\
\hline FDVit L1.(lagged) & $0.858^{*}$ & 0.056 \\
\hline Ingdp $p_{i t}$ & $0.002^{*}$ & 0.001 \\
\hline KOFFGI & 0.000 & 0.000 \\
\hline$E F W_{i t}$ & -0.000 & 0.000 \\
\hline Trade $i t$ & 0.007 & 0.021 \\
\hline$I N f_{i t}$ & -0.000 & 0.000 \\
\hline$P P_{i t}$ & $-1.11 \mathrm{e}-11$ & $8.69 \mathrm{e}-12$ \\
\hline Wald Test & $24242.63[0.000]$ & \\
\hline Sargan Test (P-value) & $8.47[0.206]$ & \\
\hline$A R(1)$ (P value) & $-4.44[0.000]$ & \\
\hline$A R(2)(P$ value) & $-0.05[0.957]$ & \\
\hline
\end{tabular}

Note: Estimated by using dynamic system-GMM estimator developed by Blundell and Bond (1998). $A R(1)$ first order and $A R(2)$ second order serial correlation test. [p values] $*, * *$ and $* * *$ are significant at $\% 1, \% 5$ and $\% 10$ levels respectively.

The results reported in Table 3 above shows that lagged dependent variable is positive and significant which shows us the use of dynamic panel estimator is suitable. The economic growth's coefficient (Ingdp) has been seen to be positive and significant in regression, suggesting that economic growth increases investors' confidence and thus increases both demand and the supply of credit from the private sector. According to Patrick (1966), in the early stages of development services 
provided by the financial system accelerate technological development and economic growth is increasing. As the development process progresses, economic growth increases the demand for financial instruments and causes the financial system to develop. Our results support 'growth lead finance' as reported by Patrick (1966), Filippidis and Katrakilidis (2014), Nasreen et al. (2020).

The coefficients of financial globalization (KOFFGI), Institution quality (EFW) and trade, inflation and population coefficients are insignificant. The results of diagnostic tests indicate that model is right specified. The null hypothesis of first order serial correlation is rejected at $\% 1$ while the null hypothesis of second order serial correlation is failed to reject. The Sargen test fail to reject the null hypothesis of over identification restriction and confirms that the instruments are valid.

Table 4: System GMM Regression Analysis using Financial Institutions as Dependent Variable

\begin{tabular}{|c|c|c|}
\hline \multicolumn{3}{|c|}{ Dependent variable: FDInst $_{i t}$} \\
\hline Variables & & \\
\hline & Coefficient & Standart Error \\
\hline FDInst $_{\text {it }} L 1$. (lagged) & $0.938^{*}$ & 0.034 \\
\hline $\operatorname{lngdp_{it}}$ & $0.001 * *$ & 0.000 \\
\hline$K^{\prime} O F F G I_{i t}$ & 0.000 & 0.000 \\
\hline$E F W_{i t}$ & -0.000 & 0.000 \\
\hline TRade $_{\text {it }}$ & 0.011 & 0.017 \\
\hline$I N f_{i t}$ & $-0.000^{*}$ & 0.000 \\
\hline$P P_{i t}$ & $-1.26 \mathrm{e}-11^{* * *}$ & $7.96 \mathrm{e}-12$ \\
\hline Wald Test & \multicolumn{2}{|l|}{$42151.89[0.000]$} \\
\hline Sargan Test (P-value) & \multicolumn{2}{|l|}{$9.63[0.141]$} \\
\hline$A R(1)(\mathrm{P}$-value) & \multicolumn{2}{|l|}{$-6.32[0.000]$} \\
\hline$A R(2)(\mathrm{P}$-value $)$ & \multicolumn{2}{|l|}{$0.41[0.685]$} \\
\hline
\end{tabular}

Note: Estimated by using dynamic system-GMM estimator developed by Blundell and Bond (1998). $A R(1)$ first order and $A R(2)$ second order serial correlation test. [p values] $*, * *$ and $* * *$ are significant at $\% 1, \% 5$ and $\% 10$ levels respectively.

Table 4 presents the results for the model which Financial Institutions Development Index (FDInst) is taken as dependent variable and FDInst (lagged), economic growth (Ingdp), Financial Globalization (KOGGFI), Institutional quality (EFW) as explanatory variables and trade opennes, inflation and population size as control variables. The results show the positive and significant coefficient of economic growth (gdp) validates that financial institutions development can be driven by economic growth (Rodrik, 1997; Levin et al., 2000; Demetriades and Law,2004).

The negative and significant coefficient of inflation infers that in the case of high inflation, banks are reluctant to provide finance on long-term basis and it adversely impact banks' ability to increase allocation of resources and through a bad monetary policy that systematically hinders the granting of credits (Khalfaoui, 2015:7). The negative sign suggests that high level of inflation creates uncertainty which is detrimental to long term investment decisions. This points to the fact that more developed financial sectors, ensure effective monetary policy through more influence of policy decisions on money demand and supply in the economies. A high-quality institutional environment vital in explaining financial development (Cherif and Gazdar, 2010) and economic growth, at the contrary, weak institutions blocking such development (Bhattacharyya and Hodler, 2014). The population of one country could suddenly become more pessimistic regarding both the government and the economy, depressing the financial stability in a systematic manner. And also the size of population may hinder the process of banking sector development in these countries.

In table 4, the results of diagnostic tests imply that model is correctly specified. The p-value of Sargen test suggest that instruments are valid and there is no problem of serial correlation at second order as expected. 
Table 5: System GMM Regression Analysis using Financial Markets as Dependent Variable

\begin{tabular}{|c|c|c|}
\hline \multicolumn{3}{|c|}{ Dependent variable: FDMar $_{\text {it }}$} \\
\hline \multirow[t]{2}{*}{ Variables } & & \\
\hline & Coefficient & Standart Error \\
\hline FDMar ${ }_{i t}$ (lagged) & $0.902^{*}$ & 0.093 \\
\hline $\operatorname{lngdp_{it}}$ & $0.002 * * *$ & 0.001 \\
\hline$K_{\text {KOFFGI }}$ & 0.002 & 0.000 \\
\hline$E F W_{i t}$ & -0.006 & 0.000 \\
\hline TRade $_{i t}$ & -0.014 & 0.040 \\
\hline INfit & 0.000 & 0.000 \\
\hline PPit & $-7.38 \mathrm{e}-13$ & $1.69 \mathrm{e}-11$ \\
\hline Wald Test (p-value) & \multicolumn{2}{|l|}{$6202.09(0.000)$} \\
\hline Sargan Test (P-value) & \multicolumn{2}{|l|}{$4.82(0.567)$} \\
\hline$A R(1)$ (P-value) & \multicolumn{2}{|l|}{$-3.47(0.001)$} \\
\hline$A R(2)$ (P-value) & \multicolumn{2}{|l|}{$-1.38(0.168)$} \\
\hline
\end{tabular}

Note: Note: Estimated by using dynamic system-GMM estimator developed by Blundell and Bond (1998). $A R(1)$ first order and $A R(2)$ second order serial correlation test. [p values] ${ }^{*},{ }^{* *}$ and ${ }^{* * *}$ are significant at $\% 1, \% 5$ and $\% 10$ levels respectively.

In Table 5, the results are estimated by the model of using Financial markets development FDMar ${ }_{i t}$ as dependent variable. The positive value of coefficient for Ingdp explains that economic growth (Ingdp) leads to the development of financial markets only if a country is equipped with certain level of legal and institutional development. Developed countries have more developed institutional structure, so that they can benefit from financial globalization in the development of equity markets. With respect to control variables, the results show that the coefficient of trade openness, population size and inflation are insignificant for our sample. The results of diagnostic tests indicate that both models have valid instruments.

\section{CONCLUSION}

This paper investigates relationship between financial development, financial globalization, institutions and economic growth using the data of eight fragile countries over the period of 1995-2017. The years of 2018 and 2019 data of the financial development index as an indicator of financial development couldn't be reached from IMF data. Because the impression of financial development is comprehensive, financial markets and financial institutions dimensions been used. Institutional quality is measured by using Economic Freedom of the World Index (calculated by Fraser Institute) aggregate of local legal system and property rights, sound money, freedom to trade internationally and regulation values. The results show that economic growth and financial development are positively related. Thanks to financial development interest rates can be determined by market conditions and financial intermediaries can minimize transaction costs and information acquisition costs can be minimized.

For less developed countries, developments in institutions are likely to have far greater direct effects on growth than financial development itself. They are also likely to have positive indirect effects through the financial system, especially when the financial system provides large amounts of credit to the private sector. When the financial system is developed, Institutional improvements can also deliver more growth.

The study also finds that high inflation slows financial development. The Fragile economies, should strengthen their macroeconomic Fundamentals in mitigating the disruptive effects of the upcoming tightening cycle. Macroeconomic policies such as monetary, fiscal and exchange rate management play a crucial role in managing the risks that financial globalization can lead to. Institutions quality help to attract financial inflows, thus, increase the scope of financial development and economic growth at the contrary, weak institutions impede such development (Bhattacharyya and Hodler, 2014). In addition, the improvement of corporate infrastructure, especially the rule of law, the effectiveness of government and property rights, will promote the development of domestic markets. As the quality of institutions and the development of the financial sector increases, it will enable economies to achieve higher growth rates in the long term. Using a composite index for financial development as dependent variable, our analysis result shows that financial development and economic growth have a complementary relationship that supports their positive effects over time. Additionally, enhancing institutional infrastructure particularly rule of law, government effectiveness and property rights 
may encourage the development of domestic markets. Especially in this period, it is the reduction of global integration that must be undertaken carefully in order to ensure the possible optimal growth and development of the economy in the countries with appropriate quality institutions. We recommend that policymakers and researchers consider the importance of financial institutions to come up with realistic estimations and policy inputs.

\section{REFERENCES}

Acemoglu, D., Johnson, S. and Robinson, J.A. (2001). The Colonial Origins of Comparative Development: An Empirical Investigation. American Economic Review, 91(5): 1369 - 1401

Acemoglu, D., Johnson, S. and Robinson, J.A. (2005). Institutions as the Fundamental Cause of Long-Run Growth, in: Philippe Aghion and Steven Durlauf (ed.), Handbook of Economic Growth, Edition 1, Volume 1, Chapter 6: 385-472. Elsevier, North Holland.

Acemoglu, D. and Robinson, J. (2006). De Facto Political Power and Institutional Persistence. American Economic Review, 96(2): 325-330.

Baltagi, Badi H. (2011). Econometrics. (5th Edition)Springer Heidelberg Dordrecht, London, New York. DOI 10.1007/978-3-642-20059-5.

Barro, R.J. (1996). Democracy and growth. Journal of Economic Growth,1,1-27. https://doi.org/10.1007/BF00163340

Baum, Christopher F. (2014). Dynamic Panel Data Estimators, EC 823: Applied Econometrics. Boston College. https://www.bc.edu/ECC/S2014/823/EC823.S2014.nn05.slides.pdf

Bekaert, G., Campbell R. Harvey, Christian Lundblad (2005). Does financial liberalization spur growth? Journal of Financial Economics,77(1), Pages 3-55, ISSN 0304-405X. https://doi.org/10.1016/j.jfineco.2004.05.007.

Bhattacharyya, S. y Hodler, R. (2014). Do Natural Resource Revenues Hinder Financial Development? The Role of Political Institutions, World Development, 57 (C), 101-113DOI: 10.1016/j.worlddev.2013.12.003

Chen J. and Quang, T. (2014). The impact of international financial integration on economic growth: new evidence on threshold effects. Economic Modelling, 42, pp. 475-489, 10.1016/j.econmod.2014.06.011

Cherif, M., Gazdar, K. (2010). Macroeconomic and Institutional Determinants of Stock Market Development in MENA Region New Results from a Panel Data Analysis. International Journal of Banking and Finance, Vol. 7, No. 1, pp. 139-159.

Chong, A. and Calderón, C. (2000). Institutional Quality and Income Distribution. Economic Development and Cultural Change, 48 (4), 761 786. https://doi.org/10.1086/452476

Coeurdacier, N. and Rey, H., Winant, P. (2020). Financial integration and growth in a risky World. Journal of Monetary Economics,112,1-21. https://doi.org/10.1016/j.jmoneco.2019.01.022

Dreher, A. (2006). Does globalization affect growth? Evidence from a new index of globalization. Applied Economics, 38(10), 1091-1110.

Dreher, A., Gaston, N. and Martens, P. (2008). Measuring globalisation - gauging its consequences. New York: Springer

Dumitrescu, E.-I. and Hurlin, C. (2012). Testing for Granger non-causality in heterogeneous panels. Economic Modelling, 29(4),1450-1460. https://doi.org/10.1016/i.econmod.2012.02.014

Demetrio, E. and García, T. (2012). Financial globalization and financial development in transition countries. Economía teoría y práctica, (36), 155-178. http://www.scielo.org.mx/scielo.php?script=sci arttext\&pid=S0188-33802012000100007\&lng=es\&tlng=en.

Demetriades, P. and Law, S.H.(2004). Finance, Institutions and Economic Growth. University of Leicester, Working paper No.04/5

Filippidis, I. and Katrakilidis, C. (2014). Institutions, policy and banking sector development: A reassessment. Czech Journal of Economics and Finance, 82(2), 93-208.

Gurley, J. and Shaw, E. (1967). Financial Structure and Economic Development. Economic Development and Culture Change, 15, $257-268$.

https://doi.org/10.1086/450226

Gygli, S., Haelg, F., Potrafke, N. and Sturm, J.E. (2019). The KOF Globalisation Index - Revisited. The Review of International Organizations, 14(3), 543-574. https://doi.org/10.1007/s11558-019-09344-2.

Kavya, T. B. and Shijin, S. (2020). Economic development, financial development, and income inequality nexus. Borsa Istanbul Review, 20(1), 80-93. https://doi.org/10.1016/i.bir.2019.12.002

Khalfaoui, H.(2015). The Determinants of Financial Development: Empirical Evidence from Developed and Developing Countries. Applied Economics and Finance, 2(4),1-9.URL: http://aef.redfame.com

Khan, M.A., Khan, M.A, Abdulahi, M.E. , Liaqat, I. , Shah, S.S.H. (2019). Institutional quality and financial development: the United States perspective. Journal of Multinational Financial Management, Volume 49, pp. 67-80.

Kosolapov, N.A.(2001). The international political organization of the globalized world: models for a medium-term prospect. Social Sciences and Modernity, 6, 141-143.

La Porta, R., Lopez-De-Silanes, F., Shleifer, A. and Vishny, R. (2002). Investor Protection and Corporate Valuation. The Journal of Finance, 57:1147-1170. https://doi.org/10.1111/1540-6261.00457 
Law, S. H., Kutan, Ali M., Naseem N.A.M. (2018). The role of institutions in finance curse: Evidence from international data. Journal of Comparative Economics, 46 (1), 174-191, ISSN 0147-5967. https://doi.org/10.1016/j.jce.2017.04.001.

Le, Hoang P. (2020). The energy-growth nexus revisited: the role of financial development, institutions, government expenditure and trade openness. Heliyon, 6(7),1-11. https://doi.org/10.1016/J.HELIYON.2020.E04369

Levin, R., Loayze, N., Beck, T., (2000). Financial intermediation and growth: causality and causes. Journal of Monetary Economics, 46 (1), 31-77. https://doi.org/10.1016/S0304-3932(00)00017-9.

Lipset, S., M. (1959). Requisites of democracy: Economic Development and political legitimacy. The American Political Science Review, 53 (1), 69-105.

Luo, Y., Zhang, C., Zhu, Y. (2016). Openness and financial development in China: the political economy of financial resources distribution. Emerging Markets Finance and Trade, 52(9),2115-2127. https://doi.org/10.1080/1540496X.2016.1186451

Mishkin, Frederic S. (2009). Globalization and financial development. Journal of DevelopmentEconomics,89(2),164-169,ISSN0304-3878, https://doi.org/10.1016/j.jdeveco.2007.11.004.

Muye, I.M. and Muye, I.Y. (2017).Testing for causality among globalization, institution and financial development: further evidence from three economic blocs. Borsa Istanbul Rev. 17 (2), pp. 117-132.

Nasreen, S., Mahalik, M. K, Shahbaz, M. and Abbas, Q. (2020). How do financial globalization, institutions and economic growth impact financial sector development in European countries? Research in International Business and Finance, Volume 54, 101247, ISSN 0275-5319, https://doi.org/10.1016/j.ribaf.2020.101247.

Neto, D. G., \& Veiga, F. J. (2013). Financial globalization, convergence and growth: The role of foreign direct investment. Journal of International Money and Finance, 37, 161-186. http://refhub.elsevier.com/S0275-5319(19)30059-5/sbref0275

Odhiambo, N.M. (2011). Financial intermediaries versus financial markets: A South African experience. International Business and Economics Research Journal, 10 (2), 7784. https://doi.org/10.19030/iber.v10i2.1795.

Patrick, H. (1966). Financial development and economic growth in underdeveloped countries. Economic Development and Cultural Change, 14(6): 174-189.

Pesaran, M. H. (2004). General diagnostic tests for cross section dependence in panels. Cambridge Working Papers in Economics 0435, 3, 1-39. doi:https://doi.org/https://ideas.repec.org/p/cam/camdae/0435.html

Prasad, E., Rajan, R. and Subramanian, A.(2007). The Paradox of Capital. Finance and Development, A quarterly magazine of the IMF, 44(1). https://www.imf.org/external/pubs/ft/fandd/2007/03/prasad.htm

Rajan, R. and Zingales, L. (2003). Banks and Markets: The Changing Character of European Finance. National Bureau of Economic Research Working Paper, No. 9595. http://www.nber.org/papers/w9595.

Rey, H. (2013). Dilemma not Trilemma: The Global Cycle and Monetary Policy Independence. Economic Policy Symposium Background Paper. Federal Reserve Bank of Kansas City, Jackson Hole, WY.

Rodrik, D.(1997). iTFPG Controversies, Institutions and Economic Performance in East Asia. î National Bureau of Economic Research Working Paper: 5914.

Roodman, D. (2006) revised (2008). How to Do xtabond2: An Introduction to Difference and System GMM in Stata. Center for Global Development, Working Paper Number 103,pp.1-50. http://dx.doi.org/10.2139/ssrn.982943.

Ruiz, J. L.(2018). Financial development, institutional investors, and economic growth. International Review of Economics and Finance, 54,218-224. doi:10.1016/j.iref.2017.08.009.

Schumpeter, J.A. (1912). The Theory of Economic Development (2004 version), Transaction Publishers, New Brunswick, New Jersey.

Şamiloğlu, F., and Savaş, B. (2010). Financial Development and Economic Growth in Turkey: An ARDL Bounds Testing Approach. Çankırı Karatekin Üniversitesi Sosyal Bilimler Enstitüsü Dergisi, 1, 25-34.

Voghouei, H., Azali, M. and Jamali, M.A. (2011). A survey of the determinants of financial development. Asian-Pacific Economic Literature, 25:1-20. https://doi.org/10.1111/j.1467-8411.2011.01304.x

Westerlund, J. (2007). Testing for error correction in panel data. Oxford Bulletin of Economics and Statistics, 69,709-748. doi:10.1111/j.1468-0084.2007.00477.x

Yıldız, H. and Atasaygın, S. (2015). Financial Deepening and Economic Growth: The Turkish Experience. American Journal of Economics, 5(5), 477-483.

https://www.morganstanley.com/public/Tales from the Emerging_World Fragile_Five.pdf

https://www.imf.org/en/Publications/ESR/Issues/2020/07/28/2020-externalsectorreport

https://www.fraserinstitute.org/studies/economic-freedom-of-the-world-2019-annual-report

https://ethz.ch/content/dam/ethz/specialinterest/dual/kofdam/documents/Globalization/2019/KOFGI 2019 variables.pdf 